\title{
Editorial for the special issue "Scopes of the Social Imaginary in Sociology" in the ÖZS
}

\author{
Regine Herbrik • Tobias Schlechtriemen
}

(C) Österreichische Gesellschaft für Soziologie 2019

\begin{abstract}
In this editorial, we offer an overview of research on the social imaginary. We begin by sketching the difficulties one faces when dealing scientifically with the social imaginary as an object of study, as a theoretical concept, or as an approach to studying cultural phenomena. We then collect the different lines of tradition, which have so far referred to the social imaginary within sociology. Although it often seems to play a marginal role for sociological theories, it nevertheless becomes clear how important the social imaginary is for a whole range of different approaches. In a further step, we elaborate theoretical and methodological starting points for productive research. We offer a heuristic scheme which should help to relate and classify different conceptions of and approaches to the social imaginary. Building on this, we delineate the research questions and fields of investigation which the social imaginary reveals, as well as the epistemological and social functions which it enables. Finally, we introduce the reader to the contributions of this special issue.
\end{abstract}

Keywords Social imaginary - Overview of the literature $\cdot$ Methods and fields of research on social imaginaries · Castoriadis - Sociological theory $\cdot$ Sociology of knowledge $\cdot$ Heuristics

\footnotetext{
R. Herbrik ( $₫)$

Theodor-Körner-Str. 12, 19288 Ludwigslust, Germany

E-Mail: info@regine-herbrik.net

T. Schlechtriemen

Institut für Soziologie, Albert-Ludwigs-Universität Freiburg, Rempartstraße 15, 79085 Freiburg im Breisgau, Germany

E-Mail: Tobias.Schlechtriemen@soziologie.uni-freiburg.de
} 


\section{Editorial zum Themenheft „Einsatzpunkte und Spielräume des sozialen Imaginären in der Soziologie“"}

Zusammenfassung In ihrem Editorial geben die Herausgeberin und der Herausgeber einen Überblick über die Forschung zum sozialen Imaginären. Sie beschreiben zunächst die Schwierigkeiten, die bei der wissenschaftlichen Auseinandersetzung mit dem sozialen Imaginären auftreten, wenn dieses als Untersuchungsobjekt, als theoretisches Konzept oder als Ansatz für die Analyse kultureller Phänomene in den Blick genommen wird. Im Anschluss werden unterschiedliche Forschungstraditionen und Diskurse vorgestellt, die sich bislang innerhalb der Soziologie auf das soziale Imaginäre bezogen haben. Obwohl es für soziologische Theorien häufig nur eine marginale Rolle zu spielen scheint, wird deutlich, welche Bedeutung ihm für eine ganze Reihe unterschiedlicher Ansätze dennoch zukommt. In einem nächsten Schritt werden theoretische und methodologische Ausgangspunkte für seine weitere Erforschung ausgearbeitet und ein heuristisches Schema präsentiert, das hilft, unterschiedliche Entwürfe und Zugänge zum sozialen Imaginären zu relationieren und einzuordnen. Darauf aufbauend werden schließlich Forschungsfragen und Untersuchungsfelder, die das soziale Imaginäre eröffnet sowie die epistemologischen und sozialen Funktionen, die es übernehmen kann, skizziert. Abschließend werden die Beiträge des Sonderhefts vorgestellt, miteinander in Beziehung gesetzt und in die oben angerissenen Diskurse eingeordnet.

Schlüsselwörter Soziales Imaginäres · Forschungsüberblick · Methoden und Forschungsfelder des sozialen Imaginären · Castoriadis · Soziologische Theorie · Wissenssoziologie $\cdot$ Heuristik

\section{The social imaginary as a challenge for sociological research}

The social imaginary is a challenging object for sociological research in several respects. As an object of study, the imaginary largely evades attempts at quantification or explanation in terms of causal relationships. Its reality status, and hence its relevance as an object of scientific inquiry, is all too quickly denied. After all, it is "imaginary" and not "real". The social imaginary exacerbates this problem, because as individual fantasy, the imaginary can still be described as belonging to a person's experiential horizon. In the case of the social or societal imaginary, the scope of the imaginary is open and first needs to be defined.

Against this backdrop, it is astounding that the social imaginary indeed does play a part in several sociological approaches, albeit usually a subordinate one. This applies, for instance, to Durkheim (1998), who attributes a community-building function to the projection of a second reality in interplay with a collective emotionality (effervescence) in his remarks on the elementary forms of religious life. As Tappenbeck (1999) also demonstrates, several classical authors of sociology postulate that the power of imagination as the aptitude for engaging in representational thought forms a kind of anthropological constant. Max Weber describes culture as "a finite segment of the meaningless infinity of the world process, a segment on 
which human beings confer meaning and significance" (Weber 1949, p. 81). Even though he is often cited as an exponent of rationalism, he argues that we need to construct "unreal" causal relationships to identify the "real". In similar fashion, Simmel emphasizes the significance of the imaginations we employ to bridge the gaps in our knowledge of the others we encounter (Simmel 1992). Mead's (1969) account of "role-taking," which is necessary for the formation of identity, entails fantasy or imagination as a presupposition. In the work of Schütz (2004 and later Schütz and Luckmann 2003), we encounter the act of imagining in several respects (cf. also Herbrik 2011). On the one hand, it is a necessary precondition for human action, as it is possible only through the power of imagination to establish a plan of action, which Schütz regards as the precondition for every action. On the other hand, however, Schütz and Luckmann also describe a form of imagining that is disconnected from all concerns in the world of action and occurs in "worlds of imagination" (2003, p. 61).

On the whole, however, the social imaginary appears only at the fringes of sociological debate. It does not belong to the canon of sociological concepts and is accordingly not included in introductions to or dictionaries of sociology (cf., for instance, Farzin and Jordan 2008). If we take a closer look at the role the social imaginary plays in the respective approaches, we can construe this marginality in a different way: For one thing, in its marginal position, the social imaginary often performs a constitutive function within an approach. Luhmann, for instance, uses the imaginary to refer to that which evades differentiation (as its unity) and hence observation (cf. 1990, pp. 716-719). Here, Luhmann compares the role of the imaginary with imaginary numbers in mathematics, which are needed for certain arithmetical operations, yet are confronted with the actual relationship to the real numbers. Although Luhmann alludes thereby to the constitutive role of the imaginary, he does not pursue the issue any further, as Werner Binder demonstrates (in this special issue). With regard to the object of sociological inquiry, society, the social imaginary can step in where the unity of society is concerned, as well as society's lack of grounds and its creative source, as Heike Delitz shows in her contribution.

Moreover, boundary phenomena are explored repeatedly in connection with the social imaginary. This includes reflections on death, the radical other, the abject, art, etc., in other words, questions and experiences located at the limits of that which can be discussed and approached in rational terms. Yet it is clear that these phenomena — even if they cannot be rendered entirely in discourse - play an essential role for our lives and our self-understanding. Those who inquire into the social imaginary are more likely to give space to such boundary phenomena. It may thus be concluded that the social imaginary is a difficult object from a scientific perspective, but upon closer consideration, these difficulties might present possibilities that merit more thorough examination. The exploration of the social imaginary would then constitute a "paradigm-in-the-making" (Adams et al. 2015, p. 15), as the editors of the journal Social Imaginaries state.

As indicated above, there are already a great many approaches that deal with the social imaginary. The social imaginary has been in vogue repeatedly in the past decades, and its relevance for sociology is strengthened further by the "cultural turn in sociology" (Moebius 2009, p. 9, our translation). After all, cultural studies 
have recently also cited the imaginary as a trans- or a-subjective aspect of cultural meaning, while it is dealt with in the international discourse as a means of breaking up conventional analytical classifications (cf. Arnason 1989). At the same time, the social or rather political imaginary is becoming a productive political scientific variable (cf. the contributions by Diehl and Langenohl in this special issue) that can help to explain current political developments and replace supposedly antiquated terms (like ideology or utopia). However, the intended meaning of social imaginary can sometimes vary considerably. This is particularly the case when one compares the German, French, and English debates across linguistic boundaries. Several French approaches, for instance, follow the works of C. G. Jung in their investigation of archetypical figures of the imaginary (cf., e.g., Durand 1979), whereas this connection breaks off in the German-language discussion after the Second World War. In English, it is possible to speak in the plural of social imaginaries, whereas in German the term exists only in the singular. It may also be observed that the social imaginary is taken up on all possible occasions to solve any problem regarding content as well as methodology. On account of the vagueness of the term, it then serves as a stopgap in widely disparate constellations. Both the different and unmediated conceptions of the term and its often seemingly arbitrary use serve as indications that we still lack in-depth, comparative research that works out the particular characteristic features of the social imaginary. The articles in this special issue make a valuable contribution to filling this gap.

\section{Key points for researching the social imaginary}

The critical first step toward an adequate understanding of the social imaginary is to stop opposing it to some form of "reality". As seen in opposition to such a "reality", the imaginary is then either regarded as a secondary, a derived, or a "merely thought-up" reality. This devaluation of the imaginary, of worlds of images and fantasy, may already be found in Plato and stays persistent through Western intellectual history all the way up to current debates. Fantasy and the imagination, on the other hand, have - starting in the field of aesthetics—been recognized as an independent and productive capacity since the 18th century, and art, the fictitious, has henceforth been ascribed an intrinsic value. However, this still only pertained to individual worlds of imagination. It was essentially only in the 20th century that various thinkers began inquiring into the social imaginary as an independent and constitutive part of social reality. This perspective allows investigation of the process of transforming a collective belief in particular fantasies into social reality via corresponding acts-such as the dynamics of the self-fulfilling prophecy, as already described by Robert K. Merton (cf. 1948)—or into the literary production of factuality and plausibility. These are both examples of research questions that can only be raised when the imaginary is no longer regarded as strictly opposing reality. The task is then to study the various forms of expression of the social imaginary in their inherent dynamism, their specific effects and modes of functioning.

This leads to questions about the extent to which inquiry into this object involves specific methodological requirements and whether the social imaginary can serve 
Fig. 1 Dimensions of the imaginary

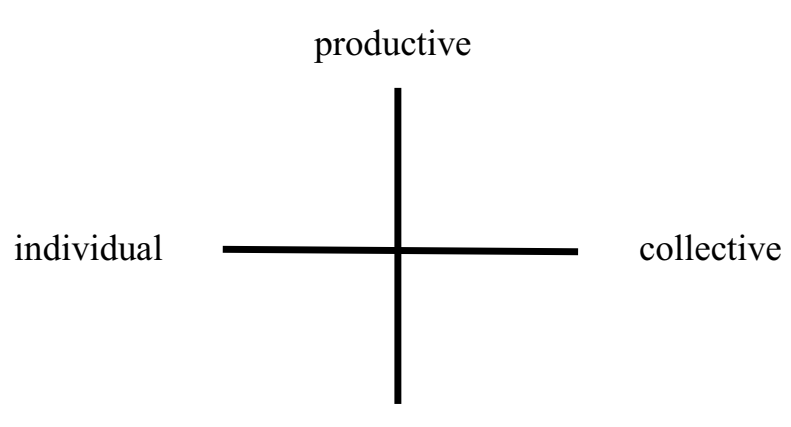

reproductive

as a sociological instrument. When the object defies, on account of its distinctive features, all attempts at being quantified through measurement as well as being forced into a fixed definition, it is necessary to select other approaches and other criteria to judge the quality of the corresponding sociological studies. What methods and theoretical perspectives might be suitable for studying the social imaginary? What criteria might be drawn on to assess such studies and research contributions? Can the social imaginary be used as a tool in sociological research? What can the concept of the social imaginary achieve in the context of sociological methodology and theory formation, and what new perspectives and problematizations does it enable?

In our view, the point of departure for answering these questions lies in a heuristic understanding of sociological theory formation and descriptions, as already formulated by Weber in relation to his ideal types (cf. 1949). Following Andrew Abbott, we might add that there is not one true, all-encompassing theory but rather several competing theoretical perspectives. They can be tested to determine what they are able to articulate, what they allow us to understand, whether they are convincing in social communication, and not least whether or not they open up new ways of looking at social realities (cf. Abbott 2004, pp. 211-248). We understand the contributions in this volume as tests of this kind, in which it should become apparent whether research into the social imaginary reveals new perspectives on an object, whether it makes previously hidden dynamics and connections visible, and whether it produces convincing interpretations.

A fundamental concern of this special issue is to work out the differences between the various conceptions of the social imaginary, as well as their genealogies and common points, and to shed light on initial subdomains of this broad field of research. This will also involve initiating a dialogue between the approaches to and concepts of the social imaginary in the French-, German-, and English-language debates, which have previously existed next to each other in relative isolation. Is it possible to forge links between Benedict Anderson's "imagined communities" (1991) and Michel Maffesoli's concept of "neotribalism", (1996) which is also oriented toward the imaginary? What intersections and differences exist between the philosophy of life tradition of Bergson or Deleuze and their understanding of images 
and the phenomenological sociology of Schütz and Luckmann and their hermeneutic approach to the imaginary?

To provide an initial, rough classification of the different understandings of the social imaginary, we propose a four-sided schema as a heuristic (Fig. 1). ${ }^{1}$

The first axis represents the field of tension between individual and collective expressions of the imaginary. The sociological focus lies on the side of the social, collective imaginary. But it is precisely as fantasy, as the imaginative creativity of the genius - and later also in the form of the creativity all subjects need to shape their own lives - that the individual side repeatedly comes into play. This raises the question of how individual and collective fantasies are mediated (cf., for instance, the contribution by Schünzel). The approaches that enter into the picture in this regard are those that have made psychoanalysis productive for social theory, such as that of Ernesto Laclau and Chantal Mouffe (2001). With regard to the imaginary as a sociological tool, approaches centered on individual protagonists stand opposite to approaches centered on groups or collectives.

The second axis differentiates between productive and reproductive forms of the imaginary-Adams and colleagues make a distinction here between "creative" and "imitative" (2015, p. 16). Here, too, the two outermost poles do not appear in their pure forms but refer to an essential difference. In some cases, the imaginary focuses on creativity, on the possibility of making something new (Sartre), of acting or beginning something (Arendt), of planning and of dreaming, or even on the irreducibility of images (Blumenberg) and hence on the productive side of the imaginary. On the other hand, there are ideas, memories of things past, images as copies, or mimetic imitations - forms of the imaginary in which there is a foreign reference, a connection to something else that is reproduced in various ways. Here, too, sociological studies can place more emphasis on creativity and that which is new, or they can focus more on that to which something refers-in any case, it is useful to keep both functions of the imaginary in mind. For example, one might place Castoriadis' approach of the radical social imaginary in the upper right-hand corner of the schema, because he is concerned with the collective and creative act of societal self-institution (cf. Castoriadis 1997). But again, this very simple schema is meant as a heuristic tool for achieving an initial classification, which will then need to be explicated in more detail in the following.

\section{Research questions on the social imaginary}

What research questions and fields of study does the social imaginary unclose? 1) Conceptual deepening: The descriptions above initially serve as a basis for a conceptual and historical deepening (an example of this is the contribution by Delitz). Where can the social imaginary be found in the classics and in more recent sociological approaches? How is it conceived there, and what influence does it exert on theory formation? This is followed by comparative issues that investigate the

\footnotetext{
1 This schema came up in discussions with Charlton Payne and Florian Sedlmeier while preparing the workshop "Einsätze des Imaginären (Uses of the Imaginary)" at the University of Konstanz in 2008.
} 
different genealogies of the concept and work out the translation processes the social imaginary experiences in its global circulation (cf. Keim 2016; Valaskivi and Sumiala 2014).

2) Research fields: The research fields of the social imaginary are varied and manifold; hence, there is not a single ratio but various rationalities, not a single Western modernity but multiple modernities, just as there are different understandings of the self and the world. In addition, the social imaginary is suitable for considering that which is not mediated through discourse or pushes the limits of that which can be said or grasped, that which occurs prior to reflection, and that which is determined by affective and sensory dynamics (cf., e.g., the understanding of imaginaries that Kagan develops in his contribution). On the one hand, this is about issues concerning affective and somatic effects. On the other hand, it involves taking a look at boundary phenomena of the social, not least all forms of the sacral or religious as well as art (cf. the contribution by Knapp).

A central topic in research on social imaginaries is "the ways people imagine their social existence" (Taylor 2004, p. 23), the images in which social groups and collectives describe themselves (cf. Lüdemann 2004; Schlechtriemen 2014; Gilleard 2018). These collective representations of society, but also of the nation or postnational formations, of cities (cf. the contribution by Schwenk), and fundamental ideas about Western modernity (cf. Anderson 1991; Taylor 2004) and its translations and questionings (Appadurai 1996, 2002; Mbembe 2002) do refer to social structures, but they cannot be reduced completely to them. This also includes imaginations of the past and of history (cf. Le Goff 1991) as well as the "imagined futures" or "fictional expectations" described by Jens Beckert (2011, p. 1). And yet the social imaginary offers a means of accessing cultural meanings, their genesis, their persistence, and their changes which is aligned more to images and their nondifferential way of generating meaning and is also more process-oriented (cf. Binder in this special issue). What patterns of cultural interpretation characterize a society? How do these social imaginaries travel through different media (cf. Lee and LiPuma 2002; Valaskivi and Sumiala 2014)?

It is then also possible to inquire into the social functions of the imaginary, because here the collective representations constitute the society as a whole, which is thus opened up for discussion as a tangible entity (cf. the contribution by Delitz). In similar fashion, large companies (cf. Puyou et al. 2012) or the market (cf. Langenohl 2016, p. 581) are dependent on being given tangible form. However, a society can also reinvent itself through its collective imaginations and initiate social change - a function emphasized particularly by Castoriadis. In its position at the periphery, the social imaginary enables various ultimate concerns that cannot be formulated within a conceptual system - a feat comparable to what Hans Blumenberg describes in relation to absolute metaphors (1999). Michel Maffesoli points out that images (as a form of the social imaginary) perform a binding function for society (cf. Maffesoli 1993). Dilip Gaonkar, too, emphasizes this community-building function of the social imaginary (cf. 2002), which Andreas Langenohl (cf. 2016) then associates with its action-oriented function and the performance of common practices. What other functions can the social imaginary perform? 
3) Interdisciplinary intersections: Charles Taylor, like many other authors that look into the social imaginary, assumes that the social imaginary "is carried in images, stories and legends" (2004, p. 23). However, the questions this raises are seldom posed: Which media serve to articulate the social imaginary, what mediaspecific means of expression and affordances are involved, and how is the multimodal interplay arranged and how can it be analyzed? Exceptions include Annette Knaut's (2016) study on gender knowledge in different media representations, that of Anja Weller und Julien Bucher (2016) on the imaginations of the lifeworld of school students using the method of the pictorial interview, or that of Anna Schünzel (in this special issue), in which she analyzes the interplay between Web images and everyday body awareness. This clearly leads to content and questions that intersect with other disciplines, such as literary and media studies. The studies of Liebsch and Sons (2018) demonstrate this. They deal with the artistic exploration of biological and genetic technologies in terms of a social imaginary and in doing so place special emphasis on the affective dimension of the relations between artists, biological engineers, societal discourse, and political conflicts. Thus, these studies reveal the interdisciplinary potential of the social imaginary - in this case between art, society, and politics. Framed in more general terms: Does the social imaginary offer an interface that can serve as an intermediary both between otherwise unconnected subject areas and between different academic disciplines? Where does a sociology conceived from the perspective of the social imaginary intersect with cultural studies?

4) Methodological issues: From an epistemological perspective, the question arises how we can adequately grasp the concept of the social imaginary if it defies attempts at definition and in part even the possibility of direct discursivation. What own ways of generating meaning and plausibility does it bring about? Is it suitable for use as a heuristic for stimulating the emotional imagination in sociological research and through "lyrical descriptions" (cf. Lim in this special issue)? Is it possible to use the social imaginary to focus on precisely such aspects of social realities that the sociological order bias leaves out of the picture (cf. the contribution by Alkemeyer and Buschmann)? And furthermore, what role does the sociological imagination play in various research questions (cf. Mills 2000; Tappenbeck 1999; and Lim in this volume)? In empirical studies, there is also a need of clarification regarding the question of what consequences for methodology and methods sociological research oriented toward the social imaginary entails.

\section{Contributions to this special issue ${ }^{2}$}

Our objective in selecting the contributions to this volume was to present as many facets of the discussion on the social imaginary as possible. The authors of the articles devote themselves to the social imaginary from a theoretical perspective, they study it through empirical means, make reference to different (including regional)

\footnotetext{
${ }^{2}$ For the help with editing and translating the texts of this special issue we like to thank Mirko Beckers, David Heyde, Wibke Liebhart, Marius Mielke and Helene Thaa as well as the Collaborative Research Center 948 "Heroes-Heroizations-Heroisms".
} 
discourses, and make it productive for various academic disciplines. Despite this diversity, however, there are also lines of discourse and citations that run through nearly all of the contributions, engaging them in a discussion with one another and providing the reader with a means of orientation. The analysis of Castoriadis' description of society as an imaginary institution, for instance, is an important point of reference for most of the articles. It becomes apparent in the process how well suited reflection on the social imaginary is to the contextualization of even major theoretical traditions in sociology and political science and the illustration of their weak points. The social imaginary seems to be consulted particularly in regard to issues where binary codifications and dichotomous distinctions are seen as antiquated and insufficient in light of empirical findings or theoretical developments. The social imaginary then assumes the role of the "third party" (cf. Eßlinger et al. 2010), which is necessary not just to tolerate the existence of ambiguities but to make them fully describable. The social imaginary is suited to this role as long as it is conceived as an element of an interdependent trinity of the real, the fictional/the symbolic and the imaginary, e.g., as a third party that explains how parts of "the real" can become fictional or symbolic. In the process, it also becomes clear that as a sociological concept, the social imaginary does not set out to replace the sociological theory of symbols but to sharpen it through differentiation and by naming the imaginary quality of the symbol or fictions.

Werner Binder draws inspiration from Castoriadis' concept of "imaginary meanings" illustrated by the magma metaphor to expose the deficiencies of current sociological theories. Taking Luhmann's systems theory and cultural sociology as conceived by Alexander and Smith as a basis, Binder demonstrates the limitations of these theories' classification systems for signs and meanings, which are typically structured by means of differentiations. Building on Koschorke (2004), who illustrates the productivity of precisely those dividing lines and gaps between the systems that are difficult to classify for the production of meaning, Binder discusses the relevance of the social imaginary for auto-poetic systems that would not be able to develop on their own. He shows that the "programs" and "codes" assumed by systems theory should ultimately be conceived as being associated with and fueled by their own historically specific social imaginary. In this way, some of that which appeared to be "contingent" from the perspective of systems theory becomes understandable as entities marked by more comprehensive cultural meanings like the social imaginary. For Alexander's and Smith's theory of culture, Binder shows how helpful it is to grasp imaginary meanings as an effective and culturally determining background that gives meaning to events and actions in their own way. At this point, Binder also shows that it is precisely within the context of the "strong program" that the historicity and creativity of the social imaginary are concealed through the schematic application of binary codes.

Paula Diehl's contribution is also based on a very precise and explorative reading of Castoriadis' classical text and describes the possibilities that arise for existing theories when they are confronted and ultimately combined with the (in this case political) imaginary. Like Binder, Diehl works out that the imaginary attains its greatest relevance for sociological interpretations precisely in processes involving the theoretical and empirical description and analysis of upheaval, rebuilding, and 
all that cannot be created by existing institutions. On the other hand, she also shows what social constructivist elements can be used to fill gaps (for instance regarding the characterization of the processes of internalization) in the description of society as an imaginary institution. Diehl's objective is to combine political representation as a producer of the symbolic (images, symbols, rituals) with its imaginary facets to open up a new perspective for the understanding of political representation. Theoretically, she forges this link by combining more recent approaches to the sociology of knowledge (Berger/Luckmann) with the theory of the social imaginary (Castoriadis). This leads to a new understanding of political representation in which it is grasped as a symbolic process with a performative effect that is also always subject to change through the creativity of the political imaginary.

From the perspective of political sociology, the imaginary gains particular relevance when established systems of interpretation or even the fundamental democratic order itself seem threatened. Andreas Langenohl takes crises of this kind (the Brexit referendum, Donald Trump's election as US president) as the starting point for his reflections on the imaginary of the democratic election. He explores the symbolic dimensions of voting, which he understands as a practice that, as a mode of political decision making, quite simply forms the empirical basis of representative democracy. At the same time, the election is more for Langenohl than the mere technical implementation of a formal procedure and may be identified with the help of the concept of the imaginary as part of a society's symbolic economy. This also reveals how concrete practices are combined at the symbolic level with general structures of meaning. The election serves, for instance, to support and strengthen the idea of a shared good that may be described as political security and transparency and as an overcoming of contingency. Langenohl exposes the staging of an election organized in this way (in the media) with regard to its focusing and concealing mechanisms, which are designed explicitly to prevent ambiguities from becoming visible.

Heike Delitz advocates the theoretical conception of a societal imaginary and accordingly understands her article as a contribution to the theory of society. To this end, her argumentation builds not just on Castoriadis but also on the French theorists Durkheim, Bergson, Lefort, and Gauchet. The precise historical derivation and sophisticated elaboration of the similarities and differences between these theoretical approaches provide Delitz a means of analyzing how societies deal with their groundlessness. The basic assumption is that they must imagine their existence in time, the unity of their members, and their differentiation from other collectives as well as their foundation-although they generally leave the imaginary production of their grounds out of account. Finally, Delitz refers to the role that ultimate concerns like "the people", "human dignity", or also "God" play in current debates, thus indicating how such an approach to the societal imaginary could be applied for an analysis of present times.

Jochen Schwenk straddles the dividing line between politics and society in his contribution on the imaginary of the city, another text that draws strongly on Castoriadis' work. Focusing primarily on the representative, creative, and political dimension of the imaginary, Schwenk aims to show that various common understandings of the imaginary in urban research can be read as facets of a common object-the imaginary of the city. The author presents three approaches, which construe the 
imaginary as (1.) orientation knowledge contributing to an understanding of the diverse meanings of the city (Wohl/Strauss), as (2.) a "generative grammar" (Lindner) that creates a web of symbolic meanings, and as (3.) a contentious political issue whose definition can lead to interpretational conflicts. Drawing on the examples of Dresden and Bremerhaven, Schwenk illustrates the third approach in greater detail. On the basis of Rehberg's (2014) analysis of the construction of present-day Dresden as a baroque artistic and cultural paradise out of a commonly shared imaginary referring to the past and strengthened further by the city's destruction, Schwenk illustrates the practical effectiveness of the imaginary of the city. The characteristics of the political dimensions of the imaginary of the city are even more clearly on display in the example of the city of Bremerhaven, which is faced with the task of creating a new identity, a new purpose, a set of symbols, and an entirely new foundation on account of the decline of its shipyard. In the process, the city experiences social conflict as a struggle for the primacy of interpretation in the search for a common imaginary.

Taking diagnoses of the present as an example, Thomas Alkemeyer and Nikolaus Buschmann illustrate in their contribution that the imaginary is not just relevant for lifeworld practice but is also capable of extending the theory of practice. It takes on an important function just at the point where existing classifications are perceived as imprecise and insufficient and where order and its status as a universal principle are called into question. In the process, the order bias of the theory of practice described by the authors is criticized for focusing so closely on the success of practices that it loses sight of that which refuses to conform to this order. At the same time, however, this allows self-reflection in the form of an observation concept that helps praxeology to see that which transcends the order yet is not located outside of it but rather still connected to it. In this way, the theory of practice regains an analytical dimension that it initially lost in the course of the practice turn and the focus on materiality: the dimension of the draft, the (re-)creation, and hence the dimension of that which precedes practice. Taking the example of present diagnoses of the environment and sustainability, Alkemeyer and Buschmann illustrate convincingly that beyond all rationality, which focuses on the feasible, there is also always a critical potential that is capable of pushing boundaries and creating something new.

If we assume that methodology is deeply rooted in theory, it should come as no surprise that analysis of the imaginary also opens up new territory for methodology. The motivation for Il-Tschung Lim's contribution is a recent sociological debate in which the discipline was accused of lacking the capacity for scientific imagination. As a means of countering this criticism, the author proposes a reorientation of sociological description modeled on "lyrical sociology" (Abbott), providing a scope not just for the powers of imagination but also for a related emotionality that is useful for empirical research. Il-Tschung Lim gives an account of Abbott's principles of a "lyrical sociology," making it clear in the process that Abbott's main objective is to capture the feeling of social reality and its emotional meaning and to forge an emotional link between researchers and the social worlds they investigate. This touches on two exceedingly complex processes: the affectation of the researchers by their research object, which puts them in a certain emotional state, and the communication of this state to the audience of the research, who by reading the 
"thin description" should also be able to experience this emotional state. Finally, Lim elucidates the potential of lyrical sociology on the basis of an ethnographic study by Didier Fassin and proposes that it be used as a sui generis type of description that is capable of placing social phenomena in a new, affective light.

Beyond theory formation and methodological issues, the imaginary opens up new perspectives for the empirical investigation of social and cultural phenomena, as Sacha Kagan demonstrates in convincing fashion in his contribution. In doing so, he refers not just to Castoriadis and the French discourse tradition on the imaginary but also and especially to the Anglo-American discourse (Taylor, Anderson, Lennon), which exerts a strong influence on international sustainability research and makes it possible to speak not just of imaginary in the singular but of imaginaries in the plural form. Kagan uses reflection on the imaginary and imagination, between which he draws a clear distinction, to investigate and classify the current landscape of research approaches on sustainability from a meta-perspective. Drawing on Robinson's idea that a sustainable world might not need more reality but more of the imaginary as a starting point, Kagan makes out four approaches to sustainability-_triple bottom-line," "sustainability transformation," "holistic healing/ biophilia," and "culture of qualitative complexity". He investigates them with regard to the "imaginaries" from which they draw their inspiration and the imaginations that they can produce. In his work, he distinguishes between ontological, epistemological, political, and modernist imagination. For Kagan, however, the study of the imaginary and imaginations does not just afford a differentiating perspective for observing the spectrum of sustainability research but can also serve as an instrument for conducting this research itself. For sustainability research that operates at an inter- and transdisciplinary level in particular, it would seem helpful to integrate creative and reflective angles into its methodological arsenal to gain a deeper understanding of different cultural contexts and the interactions between different types of perception ("embodied cognition").

With her contribution on "thinspiration," Anja Schünzel presents a study that embarks on an empirical search for the imaginary of a specific social lifeworld. The author focuses on "Pro-Ana," a translocal community of young women whose goal is to give their bodies the thinner-than-average look characteristic of anorexia. Although the actors are physically separated from each other when they perform the necessary body practices for achieving this goal, they work together via media on the imaginary, which guides their action and offers them orientation. They serve for each other as urgently needed "thinspiration" that helps them to carry through the difficult project of optimizing their own bodies against all internal and external opposition. Schünzel illustrates how the communicative construction of the imaginary in the context of physical absence on the one hand shapes each of their subjective imaginations, while on the other hand these subjective imaginations contribute to a social imaginary that is as a result updated and developed further. This involves procedures that also draw upon the powers of human imagination, either through the adoption of new perspectives regarding the body experience of others or through various means of planning in advance or remembering in retrospect the shaping of one's own body. 
Marcela Knapp's contribution clarifies that the imaginary is an object of study that is not limited to the social philosophical, sociological, and political scientific discourse but also, particularly through the transfer and refinement of Castoriadis' theory by Iser (1991), preoccupies cultural sciences via the influence of reception aesthetics. Knapp illustrates that the social imaginary establishes connections between fictional art and societal worlds of imagination. Although the imaginary is defined somewhat differently by Castoriadis, who emphasizes the act of formation for the imaginary, than by Iser, for whom it describes the phantasmic, which only receives form through fabrication, they are yet, according to Knapp, interconnected. On the basis of their interaction, the author demonstrates what influence the level of fictionality is capable of exerting on that of societal reality. At the center of her argumentation is the notion that the creation of new forms out of the imaginary must, as a precondition, involve a free play of meanings (as understood by Iser). Knapp shows that Castoriadis' imaginary, on account of its intentionality, lacks a freedom that Iser grants it by means of the game metaphor. She takes the example of the critical public reception of the stage play The Deputy by Rolf Hochhuth to develop her argument, using it to demonstrate the socially transformative power of aesthetic artifacts for the social imaginary of the protest movement of 1968 and West German society.

\section{References}

Abbott, Andrew. 2004. Methods of discovery. Heuristics for the social sciences. New York/ London: W. W. Norton \& Company.

Adams, Suzi, Paul Blokker, Natalie J. Doyle, John W.M. Krummel, and Jeremy C.A. Smith. 2015. Social imaginaries in debate. Social Imaginaries 1(1):15-52.

Anderson, Benedict. 1991. Imagined communities: reflections on the origin and spread of nationalism. London: Verso.

Appadurai, Arjun. 1996. Modernity at large: cultural dimensions of globalization. Minneapolis: University of Minnesota Press.

Appadurai, Arjun. 2002. Deep democracy: urban governmentality and the horizon of politics. Public Culture 14(1):21-47.

Arnason, Johann P. 1989. Culture and imaginary significations. Thesis Eleven 22:25-45.

Beckert, Jens. 2011. Imagined futures. Fictionality in economic action. MPIfG Discussion Paper 11(8):1-30.

Blumenberg, Hans. 1999. Paradigmen zu einer Metaphorologie. Frankfurt am Main: Suhrkamp.

Castoriadis, Cornelius. 1997. Gesellschaft als imaginäre Institution. Entwurf einer politischen Philosophie. Frankfurt am Main: Suhrkamp.

Durand, Gilbert. 1979. Les structures anthropologiques de l'imaginaire. Paris: Bordas.

Durkheim, Émile. 1998. Die elementaren Formen des religiösen Lebens. Frankfurt am Main: Suhrkamp.

Eßlinger, Eva, Tobias Schlechtriemen, Doris Schweitzer, and Alexander Zons (eds.). 2010. Die Figur des Dritten. Ein kulturwissenschaftliches Paradigma. Berlin: Suhrkamp.

Farzin, Sina, and Stefan Jordan. 2008. Lexikon Soziologie und Sozialtheorie. Hundert Grundbegriffe. Stuttgart: Reclam.

Gaonkar, Dilip. 2002. Toward new Imaginaries: an introduction. Public Culture 14(1):1-19.

Gilleard, Chris. 2018. From collective representations to social imaginaries: How society represents itself to itself. European Journal of Cultural and Political Sociology 5(3):320-340.

Herbrik, Regine. 2011. Die kommunikative Konstruktion imaginärer Welten. Wiesbaden: VS.

Iser, Wolfgang. 1991. Das Fiktive und das Imaginäre: Perspektiven literarischer Anthropologie. Frankfurt am Main: Suhrkamp.

Keim, Wiebke. 2016. The international circulation of social science knowledge. Revue d'anthropologie des connaissances $10(1): 1-41$. 
Knaut, Annette. 2016. Geschlechterwissen und das soziale Imaginäre. In Wissensforschung - Forschungswissen, ed. Jürgen Raab, Reiner Keller, 562-573. Weinheim/Basel: Beltz Juventa.

Koschorke, Albrecht. 2004. Codes und Narrative. Überlegungen zur Poetik der funktionalen Differenzierung. In Grenzen der Germanistik. Rephilologisierung oder Erweiterung? DFG-Symposion 2003, ed. Walter Erhart, 174-185. Stuttgart Weimar: Metzler.

Laclau, Ernesto, and Chantal Mouffe. 2001. Hegemony and socialist strategy. Towards a radical democratic politics. London/New York: Verso.

Langenohl, Andreas. 2016. Das ,social imaginary“ und das methodologische Prinzip der Öffentlichkeit. In Wissensforschung - Forschungswissen, ed. Jürgen Raab, Reiner Keller, 574-584. Weinheim/Basel: Beltz Juventa.

Lee, Benjamin, and Edward LiPuma. 2002. Cultures of circulation: the imaginations of modernity. Public Culture 14(1):191-213.

Le Goff, Jacques. 1991. L'Imaginaire médiéval. Paris: Gallimard.

Liebsch, Katarina, and Eric Sons. 2018. „Bio-Art“ als „,imaginäre Institution“? Zur kulturellen Produktivität künstlerischer Auseinandersetzungen mit Bio- und Gentechnologien. In Wissensrelationen. Beiträge und Debatten zum 2. Sektionskongress der Wissenssoziologie, ed. Angelika Poferl, Michaela Pfadenhauer, 726-736. Weinheim/Basel: Beltz Juventa.

Lüdemann, Susanne. 2004. Metaphern der Gesellschaft. Studien zum soziologischen und politischen Imaginären. München: Wilhelm Fink.

Luhmann, Niklas. 1990. Die Wissenschaft der Gesellschaft. Frankfurt am Main: Suhrkamp.

Maffesoli, Michel. 1993. Introduction. Current Sociology 41(2):1-5.

Maffesoli, Michel. 1996. The time of the tribes. The decline of individualism in mass society. London: SAGE.

Mbembe, Achille. 2002. African modes of self-writing. Public Culture 14(1):239-273.

Mead, George Herbert. 1969. Sozialpsychologie. Neuwied: Luchterhand.

Merton, Robert K. 1948. The self-fulfilling prophecy. The Antioch Review 8(2):193-210.

Mills, C. Wright. 2000. The Sociological Imagination. Oxford: Oxford University Press.

Moebius, Stephan. 2009. Kultur. Bielefeld: transcript.

Puyou, François-Régis, Paolo Quattrone, Chris McLean, and Nigel Thrift (eds.). 2012. Imagining organizations. Performative imagery in business and beyond. New York/London: Routledge.

Rehberg, Karl-Siegbert. 2014. Dresden als Raum des Imaginären. „Eigengeschichte“ und Mythenbildung als Quelle städtischer Identitätskonstruktionen. In Symbolische Ordnungen Beiträge zu einer soziologischen Theorie der Institutionen., ed. Hans Vorländer, 455-466. Baden-Baden: Nomos.

Schlechtriemen, Tobias. 2014. Bilder des Sozialen. Das Netzwerk in der soziologischen Theorie. Paderborn: Fink.

Schütz, Alfred. 2004. Relevanz und Handeln I. Zur Phänomenologie des Alltagswissens. Alfred Schütz Werkausgabe, 1st edn., Vol. 6. Konstanz: UVK.

Schütz, Alfred, and Thomas Luckmann. 2003. Strukturen der Lebenswelt. Konstanz: UVK.

Simmel, Georg. 1992. Soziologie. Untersuchungen über die Formen der Vergesellschaftung. Gesamtausgabe, Vol. 2. Frankfurt am Main: Suhrkamp.

Tappenbeck, Inka. 1999. Phantasie und Gesellschaft. Zur soziologischen Relevanz der Einbildungskraft. Würzburg: Königshausen \& Neumann.

Taylor, Charles. 2004. Modern social imaginaries. Durham/London: Duke University Press.

Valaskivi, Katja, and Johanna Sumiala. 2014. Circulating social imaginaries: theoretical and methodological reflections. European Journal of Cultural Studies 17(3):229-243.

Weber, Max. 1949. "Objectivity" in social science and social policy. In On the methodology of the social sciences, 49-112. Glencoe: The Free Press.

Weller, Anja, and Julien Bucher. 2016. Visualisierte Imaginationen der Lebenswelt und der Einfluss der Medien. In Wissensforschung - Forschungswissen, ed. Jürgen Raab, Reiner Keller, 595-607. Weinheim/Basel: Beltz Juventa.

Regine Herbrik received her M.A.-degree in Sociology and German Literature from the University of Konstanz and her doctoral degree from the TU Berlin. Her doctoral thesis dealt with the communicative construction of imaginary worlds. She was post-doc fellowship holder at the cluster of excellence „Languages of Emotion“ (FU Berlin) and assistant professor for qualitative methods at the Leuphana University Lüneburg. Since March 2018, she is head of the community college (vhs) Ludwigslust-Parchim and works as extraordinary professor and lecturer in Lüneburg. 
Tobias Schlechtriemen is a Sociologist and works since 2012 as researcher in the Collaborative Research Centre (SFB) 948 "Heroes - Heroizations - Heroisms: Transformations and Conjunctures from Antiquity to the Modern Day" at the University of Freiburg. He has published Bilder des Sozialen. Das Netzwerk in der soziologischen Theorie (Images of the Social. The Network in Sociological Theory) in 2014. He currently prepares a book on Figurative Soziologie (Figurative Sociology). 